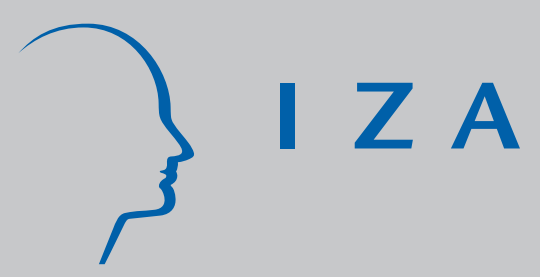

IZA DP No. 725

An Examination of Sheepskin Effects Over Time

Steffen Habermalz

February 2003 


\title{
An Examination of Sheepskin Effects Over Time
}

\author{
Steffen Habermalz \\ Marquette University and IZA Bonn
}

\author{
Discussion Paper No. 725 \\ February 2003
}

\author{
IZA \\ P.O. Box 7240 \\ D-53072 Bonn \\ Germany \\ Tel.: +49-228-3894-0 \\ Fax: +49-228-3894-210 \\ Email: iza@iza.org
}

This Discussion Paper is issued within the framework of IZA's research area Mobility and Flexibility of Labor. Any opinions expressed here are those of the author(s) and not those of the institute. Research disseminated by IZA may include views on policy, but the institute itself takes no institutional policy positions.

The Institute for the Study of Labor (IZA) in Bonn is a local and virtual international research center and a place of communication between science, politics and business. IZA is an independent, nonprofit limited liability company (Gesellschaft mit beschränkter Haftung) supported by the Deutsche Post AG. The center is associated with the University of Bonn and offers a stimulating research environment through its research networks, research support, and visitors and doctoral programs. IZA engages in (i) original and internationally competitive research in all fields of labor economics, (ii) development of policy concepts, and (iii) dissemination of research results and concepts to the interested public. The current research program deals with (1) mobility and flexibility of labor, (2) internationalization of labor markets, (3) welfare state and labor market, (4) labor markets in transition countries, (5) the future of labor, (6) evaluation of labor market policies and projects and (7) general labor economics.

IZA Discussion Papers often represent preliminary work and are circulated to encourage discussion. Citation of such a paper should account for its provisional character. A revised version may be available on the IZA website (www.iza.org) or directly from the author. 
IZA Discussion Paper No. 725

February 2003

\section{ABSTRACT}

\section{An Examination of Sheepskin Effects Over Time*}

Previous empirical specifications are not flexible enough to capture the true pattern of sheepskin effects over time. If the quality of the match between the worker and the job contributes to earnings and if higher ability workers more easily reveal their true productivity, sheepskin effects will follow a concave pattern over time. Using the NLSY and measures of actual experience, a variety of specifications (including median regressions) confirm this pattern.

JEL Classification: $\quad$ I20, I21, J31

Keywords: returns to education, sheepskin effects

Steffen Habermalz

Marquette University

Department of Economics

College of Business Administration

David Straz Hall 215

P.O. Box 1881

Milwaukee WI 53201

USA

Tel.: +1 4142883409

Email: steffen.habermalz@marquette.edu

\footnotetext{
* I would like to thank Keith A. Bender, Scott Drewianka, and especially John S. Heywood for comments and suggestions on earlier drafts of this paper and for exceptional guidance during the writing of my dissertation. Any remaining mistakes are my sole responsibility.
} 


\section{Introduction}

Hungerford and Solon (1987) began a modern series of tests investigating the existence of "sheepskin effects". They use Current Population Survey (CPS) data and estimate spline and step functions that allow for discontinuities at years where individuals usually complete their diploma and find a statistically significant and positive effect for the $16^{\text {th }}$ year of education in both specifications. Studies by Belman and Heywood (1991) and Heywood (1994) add to the literature by investigating the existence and magnitude of sheepskin effects among women and minorities and for the union/non-union and public/ private sectors respectively. Jaeger and Page (1996) address the important fact that earlier studies did not use information on actual diplomas. Using data on actual diplomas they are able to show that earlier estimates were biased downward. ${ }^{1}$

This study extends the existing research by directly examining sheepskin effects over time. Various studies have implicitly looked the time path of sheepskin effects. ${ }^{2}$ One frequent assertion is that the value of an educational signal (sheepskin effect) declines over time as employers learn about the true productivity of their workers. Layard and Psacharopoulos (1974) reject this view and use their result as evidence against the signaling hypothesis. Riley (1979) points out that in signaling equilibrium employers have to be correct on average, implying that wages can be revised upward or downward over time without affecting the average wage and the value of the signal. Thus, there is no reason for a change in the returns to an educational signal. Farber and Gibbons (1996) exploit this orthogonality between new information and the signal proposed by Riley and are able to show the constancy of the returns to an educational signal over time. Belman and Heywood (1997) stress the importance of improved matching between workers and jobs that leads to an 
increase in average productivity over time, a feature notably absent in models incorporating Riley's orthogonality condition. They develop a signaling model in which the workers' match-specific productivity depends on the quality of the job match. In their model the worker-firm match improves over time and they are able to show that returns to educational signals decrease over time. Belman and Heywood's model receives further support from Frazis (2002) who confirms that sheepskin effects are more likely to be found in a signaling model in which individuals are unsure about their true productivity when they acquire their educational signal. Habermalz (2002) argues that the 2period model used by previous researchers is too simple and develops an alternative multi-period model in which workers reveal their true productivity. He assumes that a worker's ability to reveal her true productivity is positively related to the level of the mismatch between job and worker. This leads to a concave time path in the returns to educational signals for higher ability workers. The intuition is that higher ability individuals are superior in their ability to reveal and communicate their true productivity in the case of mismatches between jobs and workers. Thus, the high ability individuals have a first mover advantage that leads to an increase in their returns to educational signals. This note tests for this pattern of sheepskin effects using data from the National Longitudinal Survey of Y outh 1979 (NLSY 79). ${ }^{3}$

Addressing this issue empirically is important because evidence of a concave time path suggests a higher present value (private return) of the sheepskin compared to a decreasing time path. The paper further adds to the existing literature on sheepskin effects by utilizing a measure of actual post-schooling experience instead of potential experience in the estimation process and by using quantile regressions to cope with the extreme sample variability in the dependent variable (log hourly real wage). 


\section{Empinical Estimation}

Table 1 reports the results of various empirical specifications. ${ }^{4}$ The first two models estimate the effect of changing between potential and actual post-schooling experience on the magnitude of the sheepskin effects for individuals in 1998. Sheepskin effects are estimated using dummy variables for the educational categories HIG H (High School/ GED ), ASBA (Associate/ Bachelor) and PROF (Professional degrees). ${ }^{5}$ Similar to the studies by Hungerford and Solon (1987) and Belman and Heywood (1997) the results show no statistically significant effect for the High School diploma. Both estimated effects of the Associate/ Bachelor degree (from15.6\% to 20.5\%) and Professional degree (from 35\% to 53.5\%) show considerable, statistically significant increases when actual experience instead of potential experience is included. ${ }^{6}$ The fact that the results differ in magnitude from those reported by Jaeger and Page (1996) is not surprising because the sample size of the NLSY 79 does not allow for the construction of separate dummy variables for every degree category. ${ }^{7}$ Model 3 estimates a regression specification that allows for a concave time path of the sheepskin effects by including two interaction terms between the degree dummies, actual experience and actual experience squared. As hypothesized both higher degrees (ASBA, PROF) show a concave time path indicated by positive and statistically significant coefficients on the interaction between the diploma dummies and actual experience and negative and statistically significant coefficients on the interaction between the diplomas and actual experience squared.

Table A1 in the data appendix shows that the dependent variable (log real hourly wage) is extremely variable. The Ordinary Least Squares (OLS) regression technique estimates a conditional mean function of the dependent variable and is by construction very sensitive to extreme data values. Instead of imposing ad-hoc exclusions on the data the 
model is re-estimated using a median regression. This technique estimates a conditional median function and is generally not sensitive to extreme values. ${ }^{8}$ The last column of table 1 shows the result of the median regression. The results again confirm the concave time pattern of the sheepskin effects in the returns to education. ${ }^{9}$ Table 2 shows the estimated sheepskin effects for Models 3 and 4 evaluated at mean experience. The results indicate that the magnitude of sheepskin effects increase when switching to a median regression method and thus confirms the influence of extreme values on the earlier results.

\section{Conclusion}

This study argues against the conventional view that sheepskin effects decline monotonically over time because employers learn about the true productivity of workers. The analysis suggests and empirically confirms a concave time path of sheepskin effects. This finding translates into a higher present value of the sheepskin effect for an individual compared to the monotonically declining case. The analysis further provides evidence on two important points. First, sheepskin effects are likely to be underestimated when a measure of potential experience is used as a proxy for actual experience. Second, it shows that using a median regression to cope with the high variability in the reported sample wages results in larger sheepskin effects. 


\section{Literature:}

Belman, D . and Heywood, J.S. (1991): 'Sheepskin Effects in the Returns to Education: An Examination of Women and Minorities', R eview of E conomics and Statistics, Vol. 73, pp. 720-24.

Belman, D . and Heywood, J. S. (1997): 'Sheepskin Effects by Cohort: Implications of Job Matching in a Signaling Model', 0 x ford E conomic Papers, Vol. 49, pp. 623-637.

Chiswick, B. R. (1973): 'Schooling, Screening, and Income', in: Solomon, L.C. and Taubman, P.J. (eds.), 'D oes College Matter?', Academic Press, New York, 1973.

D enny, K. J. and Harmon, C. P. (2001): 'Testing for Sheepskin Effects in Earnings Equations: Evidence for Five Countries', A pplied E conomics L etters, Vol. 8, pp. 635-37.

Farber, H.S. and Gibbons, R. (1996): 'Learning and Wage Dynamics', Q uarterly Journal of E conomics, Vol. 111, pp. 1007-1047.

Frazis, H. (2002): 'Human Capital, Signaling, and the Pattern of Returns to Education', O x ford E conomic Papers, Vol. 54, pp. 298-320.

Gibson, J. (2000): 'Sheepskin Effects and the Returns to Education in New Zealand: D o They Differ by Ethnic G roups?', N ew Z ealand E conomic Papers, Vol. 34, pp. 201-20. Gullason, E. T. (1999): 'The Stability Pattern of Sheepskin Effects and Its Implications for the Human Capital Theory--Screening Hypothesis D ebate', E astern E conomic Journal, Vol. 25, pp. 141-49.

Habermalz, S. (2002): 'Sequential Revealing of Information and the Returns to Educational Signals', Ph.D. Dissertation, University of Wisconsin-Milwaukee.

Heywood, J.S. (1994): 'How Widespread are Sheepskin Returns to Education in the U.S.?', E conomics E ducation Review, Vol. 13, pp. 227-234.

Hungerford, T. and Solon, G . (1987): 'Sheepskin Effects in the Returns to Education', Review of $\mathrm{E}$ conomics and Statistics, Vol. 69, pp. 175-177. 
Koenker, R. and Hallock, K. (2001): 'Q uantile Regressions', The Journal of E conomic Perspectives, Vol. 15, pp. 143-56.

Jaeger, D .A. and Page, M.E. (1996): 'D egrees Matter: New Evidence on Sheepskin Effects in the Returns to Education', Review of E conomics and Statistics, Vol. 78, pp. 733-740.

Johnston, J. and D iNardo, J. (1997): Econometric Methods, $4^{\text {th }}$ Edition, McGraw Hill, Chapter 13, 44-445.

Layard, R. and Psacharopoulos, G. (1974): 'The Screening Hypothesis and the Returns to Education', Journal of Political E conomy, Vol. 82, pp. 985-98.

Riley, J. (1979): 'Testing the Educational Screening Hypothesis', Journal of Political E conomy, Vol. 87, pp. S227-52.

Shabbir, T. (1991): 'Sheepskin Effects in the Returns to Education in a D eveloping Country', Pakistan D evelopment Review, Vol. 30, pp. 1-19. 


\section{Data Appendix}

The data for the empirical analysis were drawn from the National Longitudinal Survey of Youth 1979 (NLSY 79).

The NLSY 79 sample utilizes waves from 1979-98. This leaves 228,348 possible observations. The following adjustments were made. Observations with a missing or zero wage were deleted (89,205 deleted observations). 0 bservations with missing values for other variables needed in conducting the analysis were also deleted $(28,441) \cdot{ }^{10} 248$ Individuals reported their highest degree as something different than a B.S., B.A, Associate's degree, High School diploma or Professional degree. Since it is hard to categorize, for example, apprenticeships and other certificates those individuals were dropped. At this stage this resulted in a loss of 2657 observations. Some individuals years of education did not correspond to their highest degree (i.e. reported professional degree and less than 17 years of education) and were deleted (623 individuals, 1659 observations). ${ }^{11}$ Finally the data was adjusted to allow testing for the main hypothesis. Since the model tracks individuals with completed, terminal degrees, observations en route to the terminal degree were deleted. This reduces the data set by 14,955 observations. The final NLSY 79 data set consists of 91,431 observations. D ata on degrees use only actual reported degrees for Associate, Bachelor and Professional degrees. Individuals with those degrees were assumed to have a High School diploma. D ue to major inconsistencies between the highest degree reported and another variable that reveals if a person has a High School diploma it was assumed that individuals that competed 12 years of education possesses a High School diploma. 
Table A1: Descriptive Statistic

N LSY 79 Sample (91431 obs.)

\begin{tabular}{l|cccc} 
Variable & mean & std & Min & Max \\
\hline \hline hourly wage & 1291.60 & 33911.55 & 1 & 6000000 \\
hourly real wage & 10.23 & 256.40 & 0.01 & 41522.49 \\
log hourly real wage & 1.76 & 0.59 & -5.09 & 10.63 \\
education & 12.74 & 2.24 & 0 & 20 \\
HIG H & 0.64 & 0.48 & 0 & 1 \\
A SBA & 0.19 & 0.40 & 0 & 1 \\
PROF & 0.02 & 0.15 & 0 & 1 \\
gender & 0.51 & 0.50 & 0 & 1 \\
married & 0.44 & 0.50 & 0 & 1 \\
partime & 0.12 & 0.32 & 0 & 1 \\
black & 0.26 & 0.44 & 0 & 1 \\
other race & 0.05 & 0.22 & 0 & 1 \\
age & 27.80 & 5.03 & 16 & 41 \\
potential exp & 9.07 & 5.11 & 0 & 33 \\
actual exp & 6.01 & 4.55 & 0 & 21 \\
union & 0.16 & 0.37 & 0 & 1 \\
urban & 0.79 & 0.41 & 0 & 1 \\
number of jobs & 6.83 & 4.58 & 0 & 44 \\
AFQT - Scores & 40.54 & 28.32 & 1 & 99
\end{tabular}


Table 1* : Regression Results

(D ependent variable: Log hourly real wage)

\begin{tabular}{lcccc}
\hline & Model 1 & Model 2 & Model 3 & Model 4 \\
\hline \hline E ducation & 0.056 & 0.054 & 0.030 & 0.028 \\
& $(7.73)$ & $(7.60)$ & $(17.51)$ & $(19.86)$ \\
Experience & 0.034 & 0.033 & 0.057 & 0.044 \\
& $(4.15)$ & $(4.33)$ & $(16.75)$ & $(16.19)$ \\
Exp. squared & -0.001 & 0.000 & -0.001 & -0.001 \\
& $-(2.56)$ & $-(0.46)$ & $-(6.20)$ & $-(3.70)$ \\
High School (HIG H) & 0.002 & -0.005 & -0.029 & -0.057 \\
& $(0.07)$ & $-(0.16)$ & $-(2.18)$ & $-(5.54)$ \\
HIG H x experience & - & - & 0.009 & 0.020 \\
& & & $(2.64)$ & $(7.12)$ \\
HIG H x exp. Squared & - & - & 0.000 & -0.001 \\
& & & $-(1.90)$ & $-(5.35)$ \\
A ssociate/ Bachelor (A SBA) & 0.145 & 0.187 & 0.085 & 0.034 \\
& $(2.53)$ & $(3.41)$ & $(4.75)$ & $(2.38)$ \\
A SBA x experience & - & - & 0.029 & 0.054 \\
& & & $(6.48)$ & $(15.15)$ \\
A SBA x exp. Squared & - & - & -0.001 & -0.002 \\
& & & $-(4.27)$ & $-(11.25)$ \\
Professional (PROF) & 0.301 & 0.429 & 0.245 & 0.273 \\
& $(3.47)$ & $(5.10)$ & $(5.61)$ & $(9.89)$ \\
PRO F x experience & - & - & 0.039 & 0.054 \\
PRO F x exp. Squared & & & $(2.62)$ & $(6.16)$ \\
R ${ }^{2}$ (pseudo for median reg.) & 0.3129 & 0.3482 & 0.3067 & 0.2469 \\
\hline
\end{tabular}

* $\mathrm{t}$-values in parentheses. Model 1 estimates the sheepskin effects using potential experience for individuals in 1998 (number of observations 4985). Model 2 estimates model 1 using actual experience. Model 3 estimates the full model (num. obs. 91431) using actual experience. Model 4 estimates the model using a median regression. Other controls are: race, gender, Armed Forces Q ualification Test Scores, number of jobs, year dummies, union membership, residence in an urban area, part-time, interaction between part-time and married, married, regional dummies.

Table 2*: Cumulative Sheepskin Effects

\begin{tabular}{ccc}
\hline & Model 3 & Model 4 \\
\hline \hline HIG H & 0.016 & 0.038 \\
ASBA & 0.248 & 0.318 \\
PROF & 0.505 & 0.617 \\
\hline \hline
\end{tabular}

* Sheepskin Effectscalculated using the estimated coefficients (i.e. HIG H, HIG H*EXP, HIG H*EX ${ }^{2}$ ) and evaluating their sum at mean experience levels (HIG H=6.71, ASBA=6.31, PROF=4.83) 


\section{Endnotes:}

1 Studies investigating sheepskin effects are not limited to the United States (see for example D enny/ Harmon (2001), G ibson (2000), Gullason (1999), Shabbir (1991)

${ }^{2}$ All of the studies that have implicitly looked at sheepskin effects over time have done so in attempting to find evidence for/ against the signaling hypothesis. More specifically, they estimate returns to educational signals over time. While the existence of sheepskin effects is often taken as evidence for the signaling hypothesis, one can easily explain them within the human capital framework (see Chiswick (1973)). Therefore this study focuses on advancing the empirical knowledge of sheepskin effects and does not take their existence as evidence of either theory.

3 See the data appendix for a description of the data set.

${ }^{4}$ All regression specifications use race, gender, Armed Forces Q ualification Test Scores, number of jobs, year dummies, union membership, residence in an urban area, part-time, interaction between part-time and married, married, regional indicators as other controls.

${ }^{5}$ The dummy variables are constructed as mutual exclusive categories (i.e. an individual with a bachelor's degree is coded as $\mathrm{HIGH}=0, \mathrm{ASBA}=1, \mathrm{PROF}=0$ ).

${ }^{6}$ The percentage increase in the dependent variable associated with the dummy variables is calculated by $\mathrm{e}^{\mathrm{b}}-1$, where $b$ is the estimated coefficient.

7 Jaeger and Page (1996) report marginal diploma effects between 7\% (some College, No D egree) and 31\% (Bachelor) and 3\% (Masters) and 31\% (Professional).

${ }^{8}$ For information on quantile regressions see Johnston, J./ D iNardo, J. (1997) and Koenker, R./ Hallock, K. (2001)

${ }^{9}$ To control for the effect of heterogeneity among individuals fixed- and random-effect regressions were also carried out but not reported here. Both regression confirmed the time path of sheepskin effects reported in table 1.

${ }^{10}$ The 28,441 observations deleted were due to (in that order) missing values on region of residence (1085), residence in an urban area (2954), marital status (10), year of education (243), union membership (13788), inclusion in the military sample (3594), weeks worked since last interview (574), hours worked since last interview (1088), race of respondent (689) (revised) AFQT scores (4390), cumulative number of jobs (26). 
11123 individuals reported a professional degree and less than 17 years of education, 494 reported a B.A, B.S or Associate's degree with less than 13 years of education and 6 reported a high school diploma with less than 12 years of education. 


\section{IZA Discussion Papers}

\begin{tabular}{|c|c|c|c|c|}
\hline No. & Author(s) & Title & Area & Date \\
\hline 710 & $\begin{array}{l}\text { Z. Eckstein } \\
\text { Y. Weiss }\end{array}$ & $\begin{array}{l}\text { On the Wage Growth of Immigrants: Israel, } \\
1990-2000\end{array}$ & 2 & $02 / 03$ \\
\hline 711 & C. Ruhm & Healthy Living in Hard Times & 3 & $02 / 03$ \\
\hline 712 & $\begin{array}{l}\text { E. Fehr } \\
\text { J. Henrich }\end{array}$ & $\begin{array}{l}\text { Is Strong Reciprocity a Maladaptation? On the } \\
\text { Evolutionary Foundations of Human Altruism }\end{array}$ & 5 & $02 / 03$ \\
\hline 713 & $\begin{array}{l}\text { I. Gang } \\
\text { J. Landon-Lane } \\
\text { M. S. Yun }\end{array}$ & $\begin{array}{l}\text { Does the Glass Ceiling Exist? A Cross-National } \\
\text { Perspective on Gender Income Mobility }\end{array}$ & 2 & $02 / 03$ \\
\hline 714 & M. Fertig & $\begin{array}{l}\text { Educational Production, Endogenous Peer } \\
\text { Group Formation and Class Composition - } \\
\text { Evidence From the PISA } 2000 \text { Study }\end{array}$ & 6 & $02 / 03$ \\
\hline 715 & $\begin{array}{l}\text { E. Fehr } \\
\text { U. Fischbacher } \\
\text { B. von Rosenbladt } \\
\text { J. Schupp } \\
\text { G. G. Wagner }\end{array}$ & $\begin{array}{l}\text { A Nation-Wide Laboratory Examining Trust and } \\
\text { Trustworthiness by Integrating Behavioral } \\
\text { Experiments into Representative Surveys }\end{array}$ & 7 & $02 / 03$ \\
\hline 716 & $\begin{array}{l}\text { M. Rosholm } \\
\text { L. Skipper }\end{array}$ & $\begin{array}{l}\text { Is Labour Market Training a Curse for the } \\
\text { Unemployed? Evidence from a Social } \\
\text { Experiment }\end{array}$ & 6 & $02 / 03$ \\
\hline 717 & $\begin{array}{l}\text { A. Hijzen } \\
\text { H. Görg } \\
\text { R. C. Hine }\end{array}$ & $\begin{array}{l}\text { International Fragmentation and Relative Wages } \\
\text { in the UK }\end{array}$ & 2 & $02 / 03$ \\
\hline 718 & E. Schlicht & Consistency in Organization & 1 & $02 / 03$ \\
\hline 719 & $\begin{array}{l}\text { J. Albrecht } \\
\text { P. Gautier } \\
\text { S. Vroman }\end{array}$ & $\begin{array}{l}\text { Equilibrium Directed Search with Multiple } \\
\text { Applications }\end{array}$ & 3 & $02 / 03$ \\
\hline 720 & T. Palokangas & $\begin{array}{l}\text { Labour Market Regulation, Productivity- } \\
\text { Improving R\&D and Endogenous Growth }\end{array}$ & 3 & $02 / 03$ \\
\hline 721 & $\begin{array}{l}\text { H. Battu } \\
\text { M. Mwale } \\
\text { Y. Zenou }\end{array}$ & $\begin{array}{l}\text { Do Oppositional Identities Reduce Employment } \\
\text { for Ethnic Minorities? }\end{array}$ & 1 & $02 / 03$ \\
\hline 722 & $\begin{array}{l}\text { C. K. Spiess } \\
\text { F. Büchel } \\
\text { G. G. Wagner }\end{array}$ & $\begin{array}{l}\text { Children's School Placement in Germany: Does } \\
\text { Kindergarten Attendance Matter? }\end{array}$ & 6 & $02 / 03$ \\
\hline 723 & $\begin{array}{l}\text { M. Coles } \\
\text { B. Petrongolo }\end{array}$ & $\begin{array}{l}\text { A Test between Unemployment Theories Using } \\
\text { Matching Data }\end{array}$ & 3 & $02 / 03$ \\
\hline 724 & $\begin{array}{l}\text { J. T. Addison } \\
\text { R. Bailey } \\
\text { W. S. Siebert }\end{array}$ & $\begin{array}{l}\text { The Impact of Deunionisation on Earnings } \\
\text { Dispersion Revisited }\end{array}$ & 2 & $02 / 03$ \\
\hline 725 & S. Habermalz & An Examination of Sheepskin Effects Over Time & 1 & $02 / 03$ \\
\hline
\end{tabular}

An updated list of IZA Discussion Papers is available on the center's homepage www.iza.org. 